\title{
Analyzing Indira Parthasarathy's High Noon in Light of G.H. Mead's Theory of Self and Society
}

\author{
Jesintha Princy.J \& Sarika Gupta ${ }^{2}$ \\ ${ }^{1}$ Research Scholar, School of Social Science and Languages, VIT. ORCID: oooo-0oo1-7304- \\ 5726. Email: jesinthaprincy@gmail.com \\ ${ }^{2}$ Associate Professor, School of Social Science and Languages,VIT. \\ Email: tyagisarika27@gmail.com.
}

\begin{abstract}
The concept of self is the individual's configuration of beliefs and opinions that have the primary association to his/her own behavior, "especially those ideas considered most central and enduring in the individual's behavior" (Pasricha, 206). This organization of one's own thoughts and beliefs relatively provides a continual experience in different social situations. The exchange, evolution, participation in the social process organizes the behavior of the individual that results in the emergence of a better self. George Herbert Mead's analysis of self and society emphasizes that the existence of self without the experience in the social process is absolutely impossible. Indira Parthasarathy's penmanship is often a social criticism that is embellished with an individual's participation and response to the social setting. Analyzing the novella High Noon through the viewpoint of Mead's theory of self and society, the process of emergence of self in the individual makes our understanding of the issues better. The development and emergence of self of the two main characters Ambi and Vembu Ayyar are observed through their reflexes in the social process they are involved in.
\end{abstract}

Keywords: self, society, social setting, behavior, socio-psychology, development, emergence.

\section{Introduction:}

The development of self in individuals is a major process that defines the structuration of society. The society provides the platform for the individual to experiment and discern one's own self. For the self and the society "mutually determine and shape each other" (Bettencourt et al, 1992). According to socio-psychologists such as Charles Cooley and George Herbert Mead, society plays a major role in chiseling and developing the self in an individual. However, they differed in the process of theorizing the development of self in individuals. Cooley stated that a person's self-development is influenced by people he/she interacts with towards their entire life-span. G.H. Mead contradicted this by stating that a person's development of self does not depend on the entire people with whom he/she converses throughout his/her lifespan. Rather it is only selective people in a constructive society that influence the perception of the person's self. Mead included that the development of self is a continual process that keeps evolving throughout the life span of the person. Socio-psychologists believe that analyzing and construction of self of an individual induces a composition of society. This is because the self and society are interdependent in existence. Sociologists such as Emile Durkheim emphasized "the

(C) AesthetixMS 2020. This Open Access article is published under a Creative Commons Attribution Non-Commercial 4.0 International License (http://creativecommons.org/licenses/by-nc/4.o/), which permits non-commercial re-use, distribution, and reproduction in any medium, provided the original work is properly cited. For citation use the DOI. For commercial re-use, please contact editor@rupkatha.com. 
existence of social structure as a determinant of human thought and activity" (Brown \& Reginald, 4). Mead also stated that society plays a major role in altering and structuring the behavior of a human self. However, Mead differed from his contemporaries by embracing his theory that individuals' self is developed only through their participation in the social process. Mead stated that "the social process of experience or behavior is logically prior to the individuals and their individual experiencing which are involved in it" (Mead \& Morris, 224). The other theories which considered the idea of the self as simply internal, introspection faced a decisive turn in the field of sociology and psychology through Mead's theory of self that firmly aligned self with societal context and experiences.

Indira Parthasarathy is a renowned Tamil writer whose oeuvre often describes the correlation that corresponds between an individual and the society. His penmanship criticizes the absurdities in the society and the feeble and vulnerability of individual within the society. With efficient crafting, Parthasarathy fabricates the effect of society on the individual's self and the society affected by the perceptions and actions of an individual self. In the novella High Noon, Parthasarathy elucidates the intricacy of an individual's self and the society. The major characters in the story include Ambi and his father Vembu Ayyar who are set in the action to alter their 'self' based on their past experiences. The story with a simple narrative describes the internal struggle that evolves due to external exertions experienced by the characters to develop a better self. G.H. Mead's theory on self when paralleled with the characterization employed by Parthasarathy enables a distinct visualization of an individual's internal struggle and the role of society in building the self in an individual.

\section{Self and Society:}

The self of the individual is the accumulated set of beliefs, about the important characteristics, strengths, and weaknesses that the person possesses. Experts tag these set of beliefs as the self-concept of the individual. The self-concept provides the individual the required dossiers to tackle, accommodate, negotiate and develop social aspects and their own image in the society. For "the self-concept is heavily influenced by factors that make us distinctive" (Socio-Psychology, 106). Socio-scientists also allude to the selfconcept as a route map that enables "a sense of self that is clearly and confidently defined, providing a coherent sense of direction" (Campbell et al, 1990). The social setting and the self are the two major tracts that induce the idiosyncrasies and overall attitudes of an individual.

“The social identity is the part of an individual's self-concept which derives from (his or her) membership in a social group together with the value of emotional significance attached to the membership" (Tajfel 1981, Turner 1994).

The continuous participation of an individual in the social setting burgeons unique characteristic features and the potentialities to live and survive. It is important to understand that "the ability of humans to control, override and interrupt their responses 
(in a social setting) is a significant, important and energy-consuming aspect of the self" (Schmeichel et al, 2003).

\section{Mead's Theory of Self and Society:}

On studying the different attributes of the self and society of individuals sociopsychologists developed many theories to comprehend the reception and response behavioral status in a social setting. Beginning from the psychoanalytic theory pioneered by Sigmund Freud to the social learning theory, the coexisting self and society determines the growth of the individual's behavior and the evolution of structuration in society. Among these, the symbolic interaction theory by GH Mead illustrates the development of self is initiated from the early stage of childhood where the child takes the role of the significant other. This, in turn, results in the construction of an identity "as the creative self interacts with the social expectations of others" (Pavia et al, 109). For the expectation of others construct the social context that persuades social roles.

Mead's theory on the emergence of 'self' revealed a different perspective in analyzing the perceptions and development of an individual self. Mead states that self that emerges from a social process is "genuine and irreducible reality" (Mead, 34). The 'self arises only when it is in part of a social process where it observes, analyses the attitudes of other individuals in a community and reciprocates in the form of gestures, linguistics, and signals based on the above comprehension. The other individual in the society include parents, relatives, friends or any personality that had a significant influence on the child. They are termed as the significant others "who have in the past or in the present had an important influence on a child's attitude toward himself and the world around him" (Subberwal, 88). In describing this complex structure of self and society, Mead proposed the concept of 'I' and 'me' in an individual's self. The 'me' of the self is the social structure, what is called the 'generalized other.' The generalized other is termed as the "collective attitude, general pattern of expectations and standards" (Subberwal, 88). The 'I' is the response to the 'me', that is the individual's response to the 'generalized other.' 'Me' in the individual 'self, according to Mead is the representation of the attitudes and behaviors that are inculcated through the interaction with the society identified as the 'generalized other.' On the other hand, ' $\mathrm{I}$ ' is a reflection on the 'Me' that formulates self-conscious choices which facilitates the individual to be different both from the people in the community and the former selves. This is visible through the individual's reflections on the actions and gestures performed during his/her engagement with the generalized other.

\section{The Novella and the Theory:}

The novella begins with Ambi's arrival to his hometown Kumbakonam to visit his ill father. Vembu Ayyar, Ambi's father suffers aging and rejects conversation with the outer world. He is constantly engaged with an internal interaction, reflecting on the actions of 
his prime age. Vembu Ayyar, a conservative Brahmin, rejects Ambi's marriage with Rita Ayyar that ruptures the father-son relationship. When the married couple endeavor to fix the broken bond, Vembu Ayyar embraces his conservative thoughts and rejects the idea of reconciliation. Furious, Rita urges Ambi to discard his family ties. His denial of her idea results in a broken marriage. Ambi who resided in Delhi along with his wife Rita leaves her and reaches Kumbakonam to look after his ill father. During his visit, Ambi learns his father's internal thoughts which enables him to analyze and fix his broken marriage.

According to Mead,

"The self is something which has a development; it is not initially there, at birth, but arises in the process of social experience and activity, that is, develops in the given individual as a result of his relations to that process as a whole and to other individuals within that process" (Mead \& Morris, 139).

The social experience and societal attitude have shaped the development of self in Vembu Ayyar. Lost his father at a very early age, Vembu Ayyar decides not to imitate his father's playboy lifestyle and builds his 'self by learning. He transpires "as the lion of Vedanta and the tiger of Vyakarna" (Parthasarathy, 22). Brought up by his mother, who lost her husband at a very young age, showered Vembu Ayyar with love and became inevitable unwilling to share her son with anyone including Vembu Ayyar's first wife Avayam.

At his debilitating stage of life, Vembu Ayyar reflects on his life journey. During his internal interactions, he is constantly reminded of his first wife Avayam whom he deserted to satisfy his mother's ego. Mead suggests that a person amputates from a social phase and talks to himself/herself as they would talk to another person. Mead claims it to be significant as it is necessary to the self, and it "is this sort of social conduct which provides behavior within which that self appears" (Mead \& Morris, 140). In the case of Vembu Ayyar, it is obvious that he despises his former actions starting from his development as a conservative Brahmin. He analyses that there is no noteworthy difference that would be visible between his father's death and his own final pyre. Ayyar remarks, "I am also going to die. In his thirty years, my father lived more fully than I have done my long year" (Parthasarathy, 6). During his internal thought process, Ayyar who embraced the conservative way of living tends to empathize and comprehend the standpoints of his fellow humans i.e., the generalized others in the social setting. Starting from Sarasa's infidelity to his mother's lies for his unwavering love and attention and his injustice to his first wife Avayam. Mead indicates that the individual becomes an object to himself/herself when they take the attitude of the other individuals from the same social context or environment of behavior and encounters in which both the parties are involved. It is through taking up the attitude of others and analyzing it in order to respond, the individual

"he/she not only hears himself but responds to himself, talks and replies to himself/herself as truly as the other person replies to him/her, that we have behavior in which the individuals become objects to themselves" (Mead \& Morris, 140). 
On becoming an object to himself, Vembu Ayyar analyses his response towards the attitudes and behavior of others within the social setting. Mainly, he suffers guilt and regrets towards his response to Avayam his first wife as he objectifies his actions to the injustice he executed on Avayam. He reflects his action as a consequence to appease his mother who hated and was proved to be incapable to share her only son with interloping daughter in law. It is not only the attitude of his mother that made Vembu Ayyar desert his wife but also his past experience and rejection by his crush, Uppili's sister, that caused him to construct a prejudice on beautiful women. Mead states,

"I' reacts to the self which arises through the taking of the attitudes of others. Through taking those attitudes we have introduced the "me" and we react to it as an 'I'" (Kolb, 293).

Vembu Ayyar created his 'me' with the conclusion that all women were identical. Ayyar confesses, "My discarding Avayam and marrying Janaki was purely prompted by this idea" (Parthasarathy, 7) Vembu Ayyar realizes that Avayam has no wrong in her that is reflected in his unbelief on false stories fabricated by his mother accusing his wife. In order to reassure his love for his mother, Ayyar deposed Avayam of bad character and deserted her from his life. Mead formulates this dilemma as an interchange of functionalities between the 'Me' and 'I.' The 'Me' (the social self) acts in habitual ways, while the 'I' can reflect on these and make self-conscious choices. It is when we are not fully aware of our 'I', overcome by the 'Me' we surprise ourselves with our actions. Vembu Ayyar's contemplations on the desertion of his wife Avayam are a result of becoming consciously unconscious of the 'I' in his self and pressurized towards a more awakened ' $\mathrm{Me}$ ' that set to incline towards the attitudes of the generalized others in the social setting.

Overcome by his father's internal conflict and his constant recitation of his step-mother's name, Ambi endeavors to comprehend his motives and internal struggle. Mead describes, "One inevitably seeks an audience, has to pour himself out to somebody. In reflective intelligence, one thinks to act and to act solely so that this action remains a part of a social process" (Mead \& Mind, 173). Here Ambi seeks his best friend Murti's view towards his father's situation. Murti after much thought replies to Ambi, "You married as you wished...two of you have separated. That is what has affected the old man" (Parthasarathy, 20) Ambi taken back by Murti's response argues that his separation with his wife should please his father as he was totally against it. When Murti explains that Ambi's father is worried that his son has committed the same mistake he committed long ago to his wife Avayam. Ambi responds to Murti that it is difficult for him to forsake the "genuine sentiment towards my father and the way I grew up." Mead encapsulates that "one sees himself from the point of view of one individual or another in the group. These individuals, related all together, give him a certain self" (Parthasarathy, 21). Likewise, Murti and Ambi's father provide Ambi the other side view of his social experience. Murti advice Ambi and his wife to exclude themselves from the self-imposed privacy and urges the necessity to understand the others' selves. Murti endeavors to alter Ambi's 'Me' i.e., 
the societal attitudes and expectations imposed on Ambi thereby, enhancing his view to solve the conflict between his wife and himself. Mead suggests,

"The 'I' gives the sense of freedom, of the initiative. The situation is there for us to act in a self-conscious fashion. We are aware of ourselves, and of what the situation is, but exactly how we will act never gets into experience until after the action takes place" (Kolb, 294).

Ambi however, realizes that it is by forsaking their ego can he and his wife reconcile.

Ambi, in order to eliminate the regrets and guilt of his father, attempts to reconcile him with his past: Avayam. When he asseverates his idea to his mother she becomes obviously infuriated. For Ambi thought "mother would not object to anything in which Father's welfare was involved" (Parthasarathy, 35). Ambi was however taken back by his mother's anger. The reflection of his ' $\mathrm{I}$ ' in the social context with his was not appreciated. It is through communication that one acquires social experience. Mead argues "what determines the amount of self that gets into communication is the social experience itself" (Mead \& Morris, 142). However, Mead states that some parts of the self do not always need an expression for it is in a better relationship with itself with the outer world. This is reflected in Ambi's father who constantly ponders within himself than expressing it to the outer social setting. When Ambi details Murti about his conversation with his mother, Murti with deliberation and firmness concludes the discourse as idiotic. Murti responds to Ambi "idea should have been planned with great care but you go about it at breakneck speed" (Parthasarathy, 40). Murti comprehends Ambi's mother who is not willing to confront and reconcile with her husband's past i.e., Avayam. Mead recognizes this attitude as "we often recognize the lines of cleavage that run through us. We could be glad to forget certain things, get rid of certain things the self is bound up within past experience" (Mead \& Morris, 143). Here Janaki, Ambi's mother does not want to kindle her husband's past for it would ruin her present status in her husband's life.

Ambi on his return to Kumbakonam encounters several personalities who involve him in a social process. Individuals such as Seema and Karpambikka shatters the religious exhilarations. These two characters state the religious status of individuals in the society which indirectly influences Ambi's perspective on religion. The religious aspects his father's once deeply caressed and followed in the flow of social process seemed nothing both for Ambi and his father. Characters such as Poongavanam and Sonachalam affected Ambi to have a better examination of his marital failure. Sonachalam who was married to a beautiful wife drove her to commit suicide due to his continual physical abuse on her. When Poongavanam criticized Sonachalam that his marriage to a beautiful woman is just like handing rose garland to a monkey. This statement by Poongavanam pricks Ambi who in turn analyses the difficulty and the cause of failure in his marriage. It is only through Murti Ambi understands that it is the sense of loss of security that infuriated his wife and created an itch in the relationship. Though there were many individuals involved in the social process it is like his father, mother, and friend Murti has a significant influence on his self. Mead establishes that various elementary selves constitute a complete self which is thus the reflection of complete social process. This process that Ambi involved enabled 
him to reconcile with his wife and to view his father from a different perspective. Ambi comprehends the complication in the individual's self and the society and also the social progress that is involved in developing oneself. Ambi realizes "as slaves of foreign rulers, that society had lost all freshness and outlook and perspective. They were only custodians of empty pride confined to their homes" (Parthasarathy, 55). On this realization, he thus concludes that his "father had opposed Sweetie's coming only to keep up the empty social pretensions of this rotten lot. The opposition was now meaningless" (Parthasarathy, 55). Ambi's development of his self involves a vigorous social process where he connected with individuals around him to comprehend the social settings and to rejuvenate his self for the betterment.

\section{Conclusion:}

The development of self in an individual is through inferring the perspectives of others involved in the social contexts. Mead emphasizes that it is only through social experience the evolution of self is attained. The 'I' and 'Me' ventures the ultimate paradigm of a social process that results in an effectual development of self. In the case of Ambi, it is only after his advent to Kumbakonam the liberation of his self inaugurates. His discourse and participation in the social process enable him to achieve an enhanced viewpoint and amelioration self is progressed. In the case of Vembu Ayyar, the development of self is more internalized than the involvement in the external social process. Mead accentuates that self can be both subject and object. Ambi's development is more subjective. It is through his constant experiment and engrossment in the various social process the emergence of his self becomes absolute. Vembu Ayyar's behaviorism is the result of an experience in which the physical organism becomes the object to itself. According to Mead,

"there is always a perceptual world, that is itself a perspective within which the subjective arises, the subjective is that the experience in the individual which takes the place of the object when the reality of the object, at least in some respects lies in an uncertain future" (Lüscher, 11).

During this process, the social stimuli in the past have an effect on the individual similar to the effect or response they would receive from the generalized other. His constant lamentation of his first wife's name Avayam and his thoughts for reconciliation and forgiveness enumerates the emergence of his accomplished self.

\section{Reference:}

Campbell, J. D.. (1990). Self-esteem and clarity of the self-concept. Journal of personality and social psychology, 59(3), 538.

Tajfel, H. (1981). Human groups and social categories: Studies in social psychology. CUP Archive. 
McGarty, C. (n.d.). "Self and collective: Cognition and social context." Personality and social psychology bulletin 20.5 (1994): 454-463.

Deaux, K., Reid , A., Mizrahi, K., \& Ethier, K.a. (1995). Parameters of Social Identity. Journal of personality and social psychology, 68, 280-291.

(n.d.). "Master of one's psychological domain? Not likely if one's self-esteem is unstable." Personality and Social Psychology Bulletin 26.10 (2000): 1297-1305.

BettencoCollective Self-esteem as a mediator of the relationship between Allocentricism and Subjective Well-Being. (1997). Journal of Personality and Social Psychologyurt, B.A., \& Dorr, N. 23, 955-964.

Schmeichel, B. J., Vohs, K. D., \& Baumeister, R. F.. (2003). Intellectual performance and ego depletion: role of the self in logical reasoning and other information processing. Journal of personality and social psychology, 85(1), 33.

Swann, W.B., Jr., \& Pelham, B.W. [Embracing the Bitter truth: Positivity and Authenticity in Social Relationships.]Unpublished Raw Data. (1990).

Swann, W. B., Stein-Seroussi, A., \& Giesler, B.. (1992). Why people self-verify. Journal of personality and social psychology, 62(3), 392.

Kolb, W. L. (1944). "A Critical Evaluation of Mead's "I" And "Me" Concepts". Social Forces, vol 22, no. 3, pp. 291-296. Oxford University Press (OUP), doi:10.2307/2571973.

Mead, G. H., \& Morris, C. W. Mind, Self \& Society From The Stand-Point Of A Social Behaviorist [By] George H. Mead; Edited. (1967).

Parthasarathy, Indira. High Noon And Other Stories. Indian Writing. pp. 1- 50.50. (2008)

scher, K. (n.d.). "The social reality of perspectives: On GH Mead's potential relevance for the analysis of contemporary societies." Symbolic Interaction 13.1 (1990): 1-18.

Taylor, S., Anne Peplau, L., \& Sears, D. Social Psychology. Dorling Kindersely. pp. 306-400. (2006).

Pavia, D., Lampman, G., Kriz, G., \& Vyvyan, J. Understanding Sociology. Engage Learning India Private Limited, (2007).

Seema, Pasricha. Social Psychology. Deep \& Deep Publication, pp. 104-207.(2007)

Radcliffe-Brown, A. R.. (1940). On social structure. The Journal of the Royal Anthropological Institute of Great Britain and Ireland, 70(1), 1-12.

Mead, George Herbert, and Herbert Mind. "Self and society." Chicago: University of Chicago, 173-175, (1934).

Jesintha Princy $\mathbf{J}$ is a research scholar in the department of English, School of social science and languages, Vellore institute of technology. Her research interests include Indian English literature, cultural studies and socio-psychology.

Dr. Sarika Gupta, teaches at the department of English, School of social science and languages, Vellore institute of technology. His research interest includes Indian Literature, Indian English literature, Translated studies, Gender studies and English Language Teaching in primary and tertiary level. 